\title{
Neonatal Sepsis
}

National Cancer Institute

\section{Source}

National Cancer Institute. Neonatal Sepsis. NCI Thesaurus. Code C116802.

An infectious disorder of newborn infants that is characterized by a systemic inflammatory response most commonly caused by bacteria. 